\title{
Intracranial haemorrhage associated with ingestion of 'Ecstasy'
}

\author{
J. C. HUGHES, M. MCCABE \& R. J. EVANS
}

Accident and Emergency Department, Cardiff Royal Infirmary, Newport Road, Cardiff, Wales

\section{SUMMARY}

A case of a patient with intracranial haemorrhage thought to have been associated with ingestion of 'Ecstasy' [3-4 methylenedioxymethamphetamine (MDMA)] is presented. The case illustrates the importance of drug analysis in cases involving illicit drug use.

\section{CASE REPORT}

A 21-year-old female presented to the accident and emergency (A\&E) department No history was available from the patient but a friend stated that she had apparently taken 'Ecstasy' a number of hours earlier. She later complained of headache, dizziness and paraesthesiae in her right arm and she was put to bed. There was no history of trauma.

The next morning she was incontinent and unable to speak. On admission to the A\&E department she had signs of a complete right hemiparesis.

A CT head scan revealed a large intracerebral haemorrhage in the left frontoparietal region, with significant mass effect, and surrounding oedema with shift of the midline (see Fig. 1).

She was given mannitol and dexamethasone before she underwent a left frontoparasaggital craniotomy for removal of the intracerebral clot. At operation a small angioma was found which was felt to be the source of the haemorrhage. Drug analysis detected no MDMA but amphetamine at a concentration of $0.07 \mathrm{mgl}^{-1}$. Subsequently her speech returned but she has only partial recovery of power in her right arm and leg.

Correspondence: R. J. Evans, Accident and Emergency Department, Cardiff Royal Infirmary, Neruport Road, Cardiff, Wales. 


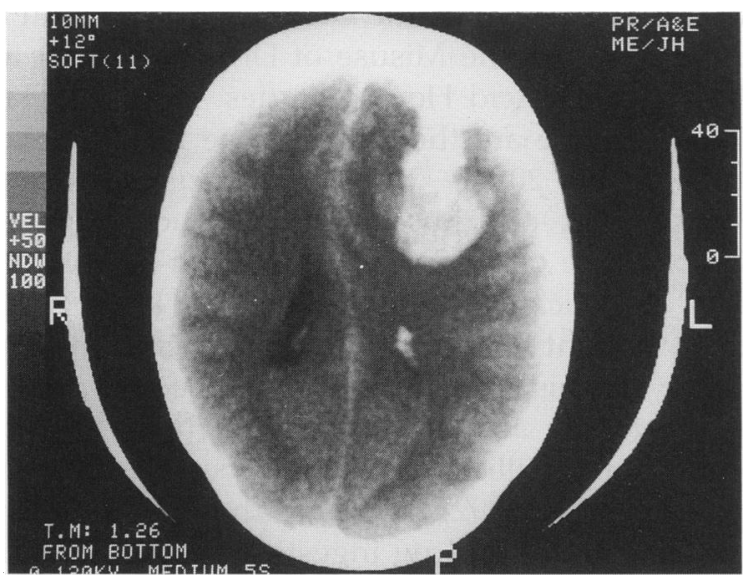

Fig. 1. CT scan showing large intracerebral haemorrhage in the left fronto-parietal region with significant mass effect and surrounding oedema with shift of the midline.

\section{DISCUSSION}

3,4-Methylenedioxymethamphetamine (MDMA), also known as 'Ecstasy', ' $X T C$ ', 'Love Doves', 'Dennis the Menace' or 'Adam' is a synthetic amphetamine derivative. The drug is taken orally as tablets or capsules in a dose of $50-150 \mathrm{mg}$.

The mechanism of toxicity is unclear but could be due to stimulation of peripheral and central alpha- and beta-adrenergic receptors. Severe reactions are unpredictable with early deaths most commonly resulting from cardiac arrhythmias and late ones (24-48 $\mathrm{h}$ post-ingestion) resulting from a syndrome resembling the neuroleptic malignant syndrome. Convulsions, collapse, hyper-pyrexia, disseminated intravascular coagulation, rhabdomyolysis and acute renal failure may occur. The long term effects are as yet unknown. Management is summarized in Table 1 .

Intracranial haemorrhage is a recognized side effect of amphetamine ingestion (Gorelick, 1990; Kaku \& Lowenstein, 1990), although not of its derivative 3-4 methylenedioxymethamphetamine.

Table 2. Management of 'Ecstasy' overdose

(1) Supportive.

(2) Oral activated charcoal $(<4 \mathrm{~h})$.

(3) Monitor Pulse, B. P., temperature for at least $12 \mathrm{~h}$.

(4) Diazepam for anxiety/agitation.

(5) Treat tachycardia with beta-blockers (e.g. atenolol).

(6) Treat hypertension with Alpha-blockers (e.g. phentolamine).

(7) Correct hypotension by volume expansion. Dopamine if necessary.

(8) If rectal temperature $>39^{\circ} \mathrm{C}$, cool and administer dantrolene.

(9) Monitor liver, renal, respiration, CPK and clotting.

(10) Correct metabolic acidosis with sodium bicarbonate. 
The recreational use of 'Ecstasy' in the U.K. has increased in recent years despite it being a Class A drug under the Misuse of Drugs Act 1971 and it is particularly associated with 'Raves' and 'Acid House' parties. A recent Harris Poll found that approximately 500000 people are thought to have taken 'Ecstasy' on at least one occasion, with an estimated 20000-30000 people using it every weekend (Harris Poll, 1992). A recent survey of school children's knowledge of drugs showed an increase in their knowledge of 'Ecstasy' (Wright \& Pearl, 1990).

While not free of complications (Dowling et al., 1987; Chadwick et al., 1991), 'Ecstasy' is generally thought by the public to be safer than amphetamines (Speed) (Henry, 1992). However, this case illustates that people may not be taking what they believe they are taking and therefore subjecting themselves to unexpected risks. A large proportion of illicit drugs may be mixtures of drugs other than that negotiated (Newcombe, 1992). It is worth taking this into account, when patients present with a history of drug ingestion of illicit drugs and rely on formal drug analysis.

\section{ACKNOWLEDGMENTS}

The authors would like to thank Dr John A. Henry for performing the toxicology analysis and Gil Beasley for typing the manuscript.

\section{REFERENCES}

Chadwick I. S., Curry P. D., Linsley A., Freemont A. J. \& Doran B. (1991) Ecstasy, 3-4 methylenedioxymethamphetamine (MDMA), a fatality associated with coagulopathy and hyperthermia. Journal of the Royal Society of Medicine 84, 371.

Dowling G. P., McDonough E. T. \& Bost R. O. (1987) 'Eve' and 'Ecstasy'. A report of five deaths associated with the use of MDEA and MDMA. Journal of the Anterican Medical Association 257, 1615-1617.

Gorelick P. B. (1990) Stroke from alcohol and drug abuse. A current social peril. Postgraduate Medicine 88, 171-174, 177-178.

Harris Poll (1992) For the BBC Television programme 'Reportage' 22 January.

Henry J. A. (1992) Ecstasy and the dance of death (editorial). British Medical Journal 305, 5-6.

Kaku D. A. \& Lowenstein D. H. (1990) Emergence of recreational drug abuse as a major risk factor for stroke in young adults. Annals of Internal Medicine 113, 821-827.

Newcombe R. (1992) A Researcher reports from the 'Rave'. Druglink Jan/Feb, 14-16.

Wrigth J. D. \& Pearl L. (1990) Knowledge and experience of young people regarding drug abuse, 1969-89. British Medical Journal 300, 99-103. 